\title{
"Service" Municipal Administration: The Main Components of Model and Its Development in Russia
}

\author{
Svetlana Eduardovna Martynova ${ }^{1}$ \\ ${ }^{1}$ Department, Tomsk State University, Tomsk, Russian Federation \\ Correspondence: Svetlana Eduardovna Martynova, Tomsk State University, 36 Lenin Ave., Tomsk 634050, \\ Russian Federation. Tel: 8-913-825-1703. E-mail: status.sm@mail.ru
}

Received: September 18, 2014

Accepted: November 7, 2014 Online Published: November 15, 2014

doi:10.5539/res.v6n4p223

URL: http://dx.doi.org/10.5539/res.v6n4p223

\begin{abstract}
Implementation of the "public service" model is possible if its components are thoroughly thought-out: purpose and functions of governing boards are definite, conditions for achieving the desired result are set, and initial condition of public management system allows the development. In the modern literature the role of local government is reduced to the execution of policy of the central government. The authors see the development of public services primarily in economic and organizational aspects. The purpose of this article is to identify the major elements of the integrated model of "public service" as a model of a new relationship between municipal authority and local community, as well as to analyze the current state of municipal administration in Russia. The analysis of scientific publications, the content analysis of sites of the Russian municipalities and the opinion poll of municipal employees were used as the main methods of research. The following article: 1) defines a set of basic elements of the "service" model for municipal administration; 2) describes the gap between the "model" and the current state of "service" municipal administration in Russia; 3) suggests social technologies for the approximation of municipal administration to the desirable state.
\end{abstract}

Keywords: municipal administration, "service" model, municipal community, social technologies, Russia

\section{Introduction}

The "service" model of public management is realized in the Russian Federation since 2003. It is regularly mentioned in official documents and speeches. It is a question of the system development of the state and municipal services. From our point of view, a full-fledged realization of this model is possible if its components (aim and functions of governing board, conditions for achieving the desired result, and initial condition of public management system) are comprehensively thought-out.

Thereupon we appeal to the scientific literature concerning a subject of "service" public management. Meanings of "public service, public service-oriented organizations, new public service", including those at the local level, imply a change of the role of governing board in society that become the "service" organizations serving needs of citizens (Cuadrado-Ballesteros, 2013; Djellal, 2013; Guardiola, 2010; Kruks-Wisner, 2011; Purcărea, 2012; Akoff, 2009; Martuzina, 2010; Richtikova, 2003; Kirienko, 2009; Stirin, 2006, etc.). Our first observation is that, except for designation of the aims of the "service" orientation, more complete view of the model is not presented in scientific works.

Authors mainly mean by "service" public administration the same processes at the state and municipal level, often noting only spread of the central government policy to the municipalities (Winters, 2014). In the Russian scientific literature "service" municipal administration is mentioned in a similar way: only in a context of the words "government and municipal administration". So, it is a question of an idea of "the service public administration implemented not only at the level of government bodies but local government" (Kozhenko, 2010), of the state and municipal services quality (Sapko, 2009). However neither in Russian, nor in foreign scientific literature the public administration is not identified with municipal administration, and vice versa. In that case it is possible to say that the "service" model of public administration at municipal level actually isn't defined.

The development of public services is mentioned within the concept of new public management (NPM), and basic provisions of this concept touch mainly economic, organizational and technological (as information and communication technologies) aspects (Gonzalez, 2013; Cuadrado-Ballesteros, 2012). If we consider these works 
in the context of "service" model, we can say that it was rather a question of a number of instruments for its implementation. Moreover, other tools, such as social technologies, almost aren't mentioned. It can be explained with the fact that NPM projects business models on the sphere of public management.

These observations motivated the objective of our work, which consists of a complex definition of the basic elements of the "service" model as a model of new relation between municipal authority and a local community

\section{Method}

Materials for definition of basic elements of model and an initial condition of public management system at the local level are: 1) the scientific works disclosing these or those parts of "service" management; 2) results of our own research conducted using the method of the content analysis of Russian municipalities sites and opinion poll of municipal employees.

\subsection{Complex of the Basic Elements of "Service" Model of Municipal Administration}

Scientific literature defines the modern objective of municipal authority as serving citizens' needs. We consider that more concrete vision of the objective and of the result may be formulated as "the increase of citizens' satisfaction with quality of municipal services". Nevertheless, as long as scientific literature mention the objective, we will address to new functions of municipal authority. To modern functions researchers attribute functions of making service orders on behalf of the citizens, as well as an organizing and coordinating its provision (Adzhiyeva, 2007). With this statement of question, the "service" setting is seen only in the word "services". However, the corresponding concept implies a deeper meaning, which also must be reflected in new functions of the municipal authority.

The service cannot be provided without the participation of its consumer. It determines participation in municipal decision-making related to the public "service." Thereupon there is a set of questions to be coordinated with municipal community: social need in a particular service and the formation of services registry; the development of social consensus concerning quality of services to be assigned in the regulatory document; the choice of service providers, and control over the compliance of their results to socially relevant quality parameters of services (or the same focus on socially important quality parameters for services provided by municipal employees). Meanwhile in the review of functions given above the role of municipal authority is looked through the interactions with one part-the service providers, while the customer, organizer and the coordinator of interactions with providers functions were carried out before.

From our point of view, new functions of municipal authority, first of all, are connected with the change of its interaction with municipal community, for which they now play the role of the "service" organizations. Accordingly, we believe that consent working out (concerning the nomenclature, quality of services and a choice of their providers) dictates moderating function as the main function of municipal authority. Such function means the organization of public dialogue (or rather a polylogue) and bringing it to the conclusions which satisfiy the subjects (if not all of them were "pro", at least, they were not con). Thereupon we agree with the opinion of R. Gonzalez, J. Llopis, J. Gasco about the necessity of cooperation, participation, negotiations, agreements for new public management (Gonzalez, 2013). In other words, governing bodies will organize the elaboration of decisions by municipal community, instead of making decision themselves. It was not peculiar to former models of public management.

Implementation of moderating function, in turn, needs additional functions for realization. For competent dialogue the municipal community has to be prepared: to have information which allows making more balanced decision. Thereupon bodies of municipal administration, in our opinion, accept the following functions: information and reference - providing the data concerning the service; education-explaining of the innovations in the service providing (for example, the description of algorithms of using electronic services, of using multipurpose centers services), and also an explanation of opportunities and algorithms of citizen participation in decision-making concerning municipal "service".

The full set of functions of municipal authority within the "service" concept, covering all parts of interaction, is presented in table 1. We can assume that, depending on subjects of interaction, instruments of functions realization also will differ: in interaction with municipal community it will be social technologies, in interaction with service providers-economic methods. 
Table 1. Dualism of functions of municipal authority within the "service" model

\begin{tabular}{lll}
\hline Interaction parties & Municipal community & $\begin{array}{l}\text { The organizations that directly } \\
\text { provide municipal education services } \\
\text { to the population }\end{array}$ \\
\hline Purpose of municipal authority & To organize decision making & To organize execution of a decision \\
\hline Functions of municipal authority & $\begin{array}{l}\text { 1. Moderating } \\
\text { 2. Information and reference }\end{array}$ & $\begin{array}{l}\text { 1. Service Customer } \\
\text { 2. Coordinator of service providing }\end{array}$ \\
& 3. Educational & \\
\hline
\end{tabular}

Detailed definition of municipal authority functions is necessary to form a "service" model. However, in spite of the fact that this analysis is carried out within discussion of tasks of the municipal management, it appears that the distribution of similar system of functions on "service" public management on the whole is proper, regardless of hierarchy. In this case, the question about specifications of "service" management at the municipal level is still open.

We address again to the analysis of the scientific literature devoted to the municipal "service". Specifications of "service" management (in particular, in the Russian Federation) are introduced in such aspects: importance of quality of municipal services and adhering to the standards, necessity of an independent/public assessment of quality, examples of demonopolization of municipal services (Gaponenko, 2003); transition to electronic government technologies at local level, creation of the service centers on the "one window" principle (Artemenko, 2010). However, according to our observations, these specifications only distribute the provisions of the general concept of "service" management at municipal level.

We considered experience of other countries with the same purpose - to identify peculiar features of the municipal "service" management. In particular, some specific features are found in the experience of Great Britain. This way, as an example there is a fact of assignment of "a set of indices and indicators of quality of the customer service functions provided by local authorities" in the Charter of the Citizen (1991). On the basis of these indicators the independent commissions give awards in the field of local management quality (Gaponenko, 2003). Possibility of a variation of the Charter of the Citizen due to local conditions is of great interest for us: in different areas the charters of services in the field of health care, public safety, fire protection, etc. are created subject to local peculiarities (Artemenko, 2010).

As it is represented, this example shows "service" decentralization that gives us the answer to the above mentioned question. We endorse views of Irina Bilouseaca, Petronela Zahariaa and Adrian Liviu Scutariua (Bilouseaca, 2012) on the importance and productivity of adaptability principle of public services to the local needs. Thus, there is a good reason to consider the distribution of the central government's policy to municipalities.

This idea finds its continuation in the aspect of social relationship. This way, authors, speaking of "service" management at municipal level with regard to the developing countries and connecting model of realization with the decentralization processes, put forward participation of citizens in management as one of the main factors of its development. In that case, when services are approached to the population, the joint management allows citizens to influence the development and the realization of everyday norms of public "service", to make decisions, which "are elastic" to local circumstances changes (Speer, 2012), correspond to local requirements (Herrera, 2014).

It's important to emphasize that citizens must not only have the opportunity to participate but also to take an active part in the development of services. A number of authors make the emphasis on an active position, participation of society in decision-making with regard to public "service" as "motive power" of development of new model of management (Winters, 2014; Asmu'i, 2014; Mehmet, 2013; Kruks-Wisner, 2011).

Thereupon it is suitable to give opinion of the Russian scientists A.I. Suchkov and Yu.I. Rybakov. These researchers speak of close social bonding and the general interest in the municipalities, especially rural (Suchkov, 2013). As a result, from our point of view, specifics of "service" municipal management can be connected with the nature of local government. However, adhering to the strict use of concepts, we will notice that existence of self-organization is a condition of the "service" model development, of a social prerequisite. It doesn't brush aside all conclusions given above, about the new purposes and functions of municipal authority (instead of local community) within the "service" concept. 
As we started the article with demonstration of Russian state aspiration to introduce "service" model (an impulse "from above"), it is logical to address to the analysis of those social prerequisites which cause its development (readiness "from below"). We will consider public involvement in municipalities in the same time frames of XXI century (according to the official documents). In the first decade of the new age it was possible to speak about rather low public involvement at the local level (Rysayev, 2010; Shatayeva, 2010; Shuba, 2010). In particular, according to G. V. Shatayeva, $63.9 \%$ of municipalities inhabitants "declared the unwillingness to participate in management of public affairs" (Shatayeva, 2010).

However, in the second decade of the XXI century the situation doesn't look so unambiguously. Already more than $50 \%$ of citizens designate the involvement into local government ("I participate actively or sometimes") in a number of territorial subjects of the Russian Federation (data from the Rostov, Nizhny Novgorod, Belgorod areas). People, who don't see the need in it, are only $13 \%$ in the Rostov region. At the same time, development of the civil participation goes unevenly. In a set of other territorial subjects of the Russian Federation (for example, Chelyabinsk region, Komi Republic, Stavropol Krai) the situation is still opposite (Zinchenko, 2013).

We assume that such unevenness is caused by a position of the municipal authorities. Where there is an aspiration of the municipal authorities to interaction, and this aspiration is realized through effective technologies of social communication, the involvement of municipal community is higher.

Thereupon we address to J. Speer's conclusions. Besides the activity of the citizens of municipalities, the author names one more condition of the development of a new model of public management. It is an interest of the officials ("mayors") in the joint management (Speer, 2012). In other works it is emphasized that the increased civil participation is initiated by the mayors (Herrera, 2014).

\subsection{The European Experience of Municipal Management}

It is necessary to highlight European Charter of Local Self-Government and the European Charter of Regional Self-Government. These regulations govern the relations on the distribution of powers between levels of government in modern Europe.

There can be distinguished two models of the distribution of powers in Europe:

A. The first one defines the powers of the municipalities as territory management and the provision of public services of communication, hygiene, public transportation; management of municipal property; protection of public order; assistance to the population; cultural and sports institutions. This model is adopted in the majority Western European countries, where communes historically have constantly expanding freedom.

$\mathrm{B}$. The second one provides that municipalities secure a number of powers to manage the territory, as well as a significant part of the functions of the state: social security, social services, education (up to a certain level), and health care. This model is common in the Scandinavian countries, and Poland and Hungary from Central Europe.

In France (first model), we see the extension of commitments and the emergence of new powers, which enables local authorities to carry out the functions of the state.

Revealing and interesting is the experience of France in terms of improving the quality of public services. History of the French system of public services and of the improvement of their relationships with their customers includes the following stages: creation of "quality circles"; development of the circular that resumed the provision of public services, which includes activities in the field of "politics of citizens reception and organizations of providing services"; creation of a "Charter for the Public Service"; development of circular on state reform in the area of improving the analysis of the needs and expectations of citizens; publishing by the Interministerial Committee on State Reform directives regarding the quality of services; established Commission on the quality of public services.

Improving the quality of services is carried out through regular evaluation of current practices of providing them and of the system of municipal governance.

The Italian system of municipal (local) management was influenced by France. Therefore, it is necessary to stop at the differences. 1. Standards of the activities of local authorities are set nationally. 2. Regional legislation has little effect on local governance. 3. Administrative regulation of local government activity becomes the exclusive competence of the region.

The territory of the Italian Republic is divided into regions with special status (statuto speciale) and normal status. Regions with special status have additional rights.

Italian territory is divided into provinces (which resemble the French departments). The lowest level of local government are the communes (comuni). All provinces (except for two autonomous ones) and all communes 
have a single unified status defined in national legislation.

The results of analysis of the experience of the EU countries show that, in accordance with administrative regulations specific ministry / government body, all laws (France, Great Britain), governmental decrees for each ministry / agency (Sweden) and an organizational plan for each ministry / department (Germany) will establish the list of public services that each of these organizational units should provide.

Russian Federation can be attributed to the second model. The tendency of recovery of local autonomy is observed.

\subsection{Current State of "Service" Municipal Authority in the Regions of Russia and Social Technologies, Promoting Development of "Public Service" at Local Level}

After defining the conditions of the development of "service" model of municipal authority, we address to a current state of the public management system of locally. This analysis allows defining a desirable and current situation and which social technologies are necessary for approaching to the desirable condition.

As we have already mentioned, our own research, devoted to the defining a degree of preparedness of the municipal authorities to the "service" activity, is carried out using the methods of the content analysis of municipalities websites and the option poll of municipal employees.

We will address to the results of the research using a content analysis. We analyzed the official websites of all 16 rural municipal districts of Tomsk region in order to find out whether the municipal authority is focused on giving an opportunity to local community to take part in all stages of development and providing municipal service. In particular, it was found if there is an opportunity for the citizens to take part: 1) in determining needs of citizens in these or those services and, respectively, in forming the nomenclature of services; 2) in forming standards of services; 3 ) in an assessment of services quality for the purpose of their subsequent adjustment by a municipal authority. In a context of our definition of municipal authorities' functions it is possible to see realization of a moderating function on the specified resource.

As a result of the analysis it is found that even the section "Municipal Services", which would directly orient the consumer on a profile subject, is present on the websites of 9 municipal districts (MD) out of 16. In other cases the information "is hidden" behind the titles "Administrative Reform", "Regulatory Legal Act", "Municipal Finance", "Municipal Authority". It indicates that orientations to the information needs and interests of the consumer under such systematization don't happen. Possibility of discussion of nomenclature, of standards and service regulations, possibility of quality assessment of services are absent at all, except for single exclusions (table 2).

Table 2. Number of websites of municipal districts of Tomsk region containing opportunities for citizens to affect the quality of municipal services

\begin{tabular}{llll}
\hline $\begin{array}{l}\text { Existence of "Municipal } \\
\text { Services" Section }\end{array}$ & $\begin{array}{l}\text { Existence of Possibility of Nomenclature } \\
\text { Discussion, Standards and } \\
\text { Regulations }\end{array}$ & $\begin{array}{l}\text { Existence of Opportunity to } \\
\text { Service }\end{array}$ & $\begin{array}{l}\text { Estimate the Quality of } \\
\text { Provided Services }\end{array}$ \\
\hline 9 of $16 \mathrm{MD}$ & 1 of $16 \mathrm{MD}$ & 1 of $16 \mathrm{MD}$ \\
\hline
\end{tabular}

This picture brings us to the conclusion that municipal authorities aren't oriented on executing the moderating function to realize the municipal "service" by means of their resource. Besides, it is quite possible that all necessary transformations and communicative technologies aren't realized in local administrations according to an innovative character of "service" model. As a result, if the "service" concept is assumed as a basic activity, it often happens only at the declarations level.

Thereupon we pay attention to the point of view of the municipal employees. It is very important to see how municipal employees find priorities in the professional competences, where personal installations belong. The concept of "public service motivation", noted in scientific literature, keeps within the logic of "service" model (Patrick, 2000; Carpenter, 2012), reflecting altruistic orientation to the service for public interests. Therefore, this personal competence - orientation on the requirements of society - has to be leading in the competences model of a modern municipal employee.

Our data were obtained as a result of the opinion poll "Intra Corporate Values in the administration of Strezhevoy" conducted in March, 2013. Strezhevoy is a small town with the population of about 45 thousand 
people. This brings it to the category of municipalities where there have to be the closest communications of municipal authorities with citizens. The research was conducted using a survey method, 71 municipal employees out of 85 were interrogated.

Data on the importance of these or those competences of opinions of the municipal employees are given in fig. 1.

Competence in the corresponding field of activity

Understanding of municipal management features

Orientation on the requirements of society, instead of the personal needs

Orientation on the obtaining the result

Responsibility

Readiness to help, attentiveness

Readiness for self-development

Creative abilities and skills

Managerial abilities and skills

Strategic thinking skills

Communicative skills

Analytical abilities and skills

Independence in decision-making
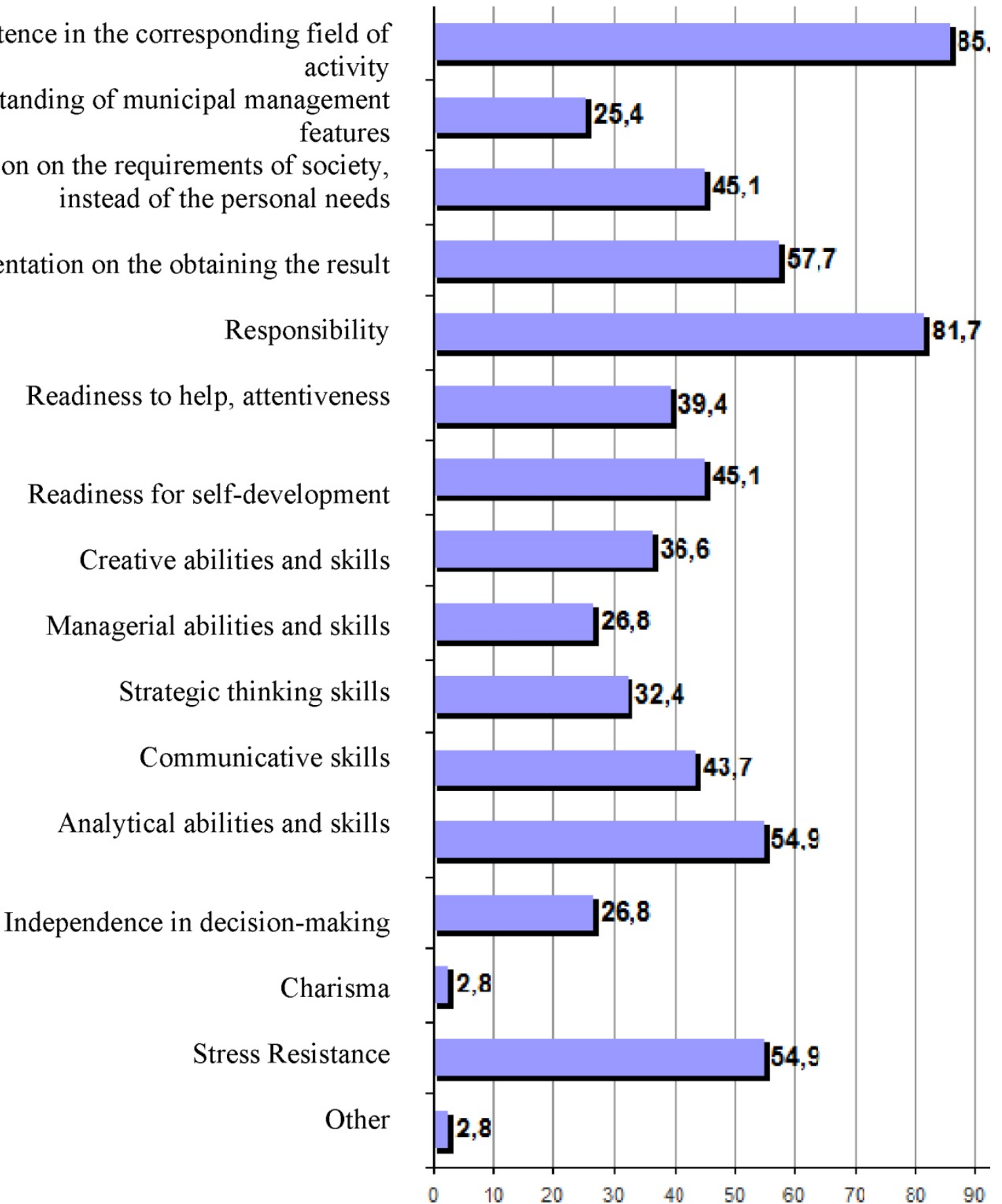

Figure 1. Answers to a question "What qualities should the municipal servant have from your point of view?" (\% of total number of respondents)

Thus, if we take into consideration 9 main competences (average number in the competences models), than the orientation to the society requirements takes only 6 th-7th position (sharing it with other competence that having 
the same importance). Municipal employees, first of all, would like to consider themselves as responsible professionals in a certain sphere. However, professionalism in aspect of branches is required in any activity (both in public management, as well as in commercial sector) and at any management paradigm. Nevertheless, employees have to be aware that they carry out their professional activity in the municipal authority and to be guided by its modern objectives and technologies.

The situation is similar in groups by a position and a length of service. The importance of orientation to the requirements of society didn't rise above the 5th place in any group. Especially attracts attention the neglecting of this competence by managers.

Table 3. The importance of orientation to the needs of society in the groups of municipal employees by a position and a length of service (a competence place)

\begin{tabular}{|c|c|c|c|c|}
\hline Head & Specialist & $\begin{array}{l}\text { Length of } \\
\text { service up to } 3 \\
\text { years }\end{array}$ & $\begin{array}{l}\text { Length of } \\
\text { service from } 3 \\
\text { to } 8 \text { years }\end{array}$ & $\begin{array}{l}\text { Length of } \\
\text { service more } \\
\text { than } 8 \text { years }\end{array}$ \\
\hline 9 & 7 & 6 & 9 & 5 \\
\hline
\end{tabular}

To sum up, we can conclude that municipal employees haven't understood the public management paradigm change and, respectively, they haven't reorientated to the new functions and social technologies yet. Thereupon our conclusion confirms the observation expressed in the scientific literature, that small municipalities are less inclined to innovations (Gonzalez, 2013). We would like to add that such situation happens there where the innovations are needed most of all, because public services are approached to the consumers as much as possible.

\section{Results}

The results of our research allow formulating a number of conclusions:

1) The complex of basic elements of the "service" municipal authority model as the model of new relationship of governing bodies with local community contains the following provisions:

- the purpose of "service" municipal authority is increasing satisfaction of citizens with the municipal services quality;

- modern functions of municipal authorities are connected, in a first place, with a change of interactions of these authorities with local community, for whom they now act as the "service" organizations;

- the position of the "service" organization means that, unlike a former paradigm of management, municipal authorities don't make decisions now. They organize the development of decisions by local community. Thus, municipal authority becomes the most participative;

- need of consent development concerning municipal "service" causes the following municipal authorities functions of interaction with local community: moderating (it is the main one), informative and educational (these are auxiliary);

- conditions of the "service" model realization are the activity of the municipalities citizens and motivation of municipal employees, and their managers in a first place.

2) Current state of the citizens' activity in municipalities of Russia shows that activity in the first decades of the XXI century gradually grows. However, heterogeneity of dynamics in regions allows assuming that growth depends on an aspiration of municipal authorities to the interaction with local community.

3) Current state of municipal management shows rather an absence of deep comprehension of new functions and, respectively, an orientation of municipal employees and, in particular, heads, on "service" installations and social technologies. Thus, from the point of view of the obtaining the goal of "service" municipal management, we say that the development of the model of new relationship between governing bodies and local community is at the initial stage.

4) The purpose can be achieved by the social technologies focused on: 1) consent development in local community concerning municipal "service", 2) formation of "service" corporate culture in the municipal authority office.

5) The reason for the importance of realization of these social technologies is that at the municipal level, 
especially in small municipalities, innovations are needed the most because public services are approached to the citizens as much as possible.

The analysis showed that the search for effective forms of municipal government continues in Europe and in the world. Each country is characterized by its own model and its own features, but we noticed a lot in common.

In Russia there is untapped potential of effective municipal governance. There should be clearly defined tasks, resources and expectations to make the change today. Constant evaluation of municipal management and learning of the foreign experience will allow achieving the desired result.

\section{Acknowledgement}

The article is prepared within the Competitiveness Improvement Program of Tomsk State University. The author is grateful to Tomsk state university for organizational and financial assistance.

\section{References}

Adzhiyeva, A. M. (2007). Management of social development of municipalities: author's abstract for candidate of sociological sciences. Abstract of the Thesis for the Candidate of Sociological Sciences. Moscow, Russian Presidential Academy of National Economy and Public Administration.

Akoff, R. L. (2009). Outside a socialism and capitalism: developing society. Problems of management in social systems, 1(1), 112-140.

Artemenko E. A. et al. (2010). Questions of Optimization of Providing Municipal Services with the Help of Information and Communication Technologies. Moscow: Vysshaia shkola ekonomiki.

Asmu'i, R. F. (2014). Applying Interactive Planning on Leadership in the Organization: The Case of Transforming Public Transport Services in Banjarmasin. Procedia-Social and Behavioral Sciences, 115, 283-295. http://dx.doi.org/10.1016/j.sbspro.2014.02.436

Bilouseaca, I., Zahariaa, P., \& Scutariua, A. L. (2012). Comparative aspects regarding the management of Swiss and Romanian local public services. Neuchatel and Suceava Cases. Procedia Economics and Finance, 3, 1024-1029. http://dx.doi.org/10.1016/S2212-5671(12)00268-7

Carpenter, J., Doverspike, D., \& Rosanna F. M. (2012). Public service motivation as a predictor of attraction to the public sector. Journal of Vocational Behavior, 80, 509-523. http://dx.doi.org/10.1016/j.jvb.2011.08.004

Cuadrado-Ballesteros, B., García-Sánchez I.-M., \& Prado-Lorenzo J.-M. (2012). Effects of different modes of local public services delivery on quality of life in Spain. Journal of Cleaner Production, 37, 68-81. http://dx.doi.org/10.1016/j.jclepro.2012.06.008

Cuadrado-Ballesteros, B., García-Sánchez, I.-M., \& Prado-Lorenzo, J.-M. (2013). Effect of modes of public services delivery on the efficiency of local governments: A two-stage approach. Utilities Policy, 26, 23-35. http://dx.doi.org/10.1016/j.jup.2013.04.005

Djellal, F., Gallouj, F., \& Miles, I. (2013). Two decades of research on innovation in services: Which place for public services? Structural Change and Economic Dynamics, 27, 98-117. http://dx.doi.org/10.1016/j.strueco.2013.06.005

Gaponenko, A. L. (2003). Application of new technologies of management in regional and municipal government. Retrieved from http://www.koism.rags.ru/publ/articles/03.php

Gonzalez, R., Llopis J., \& Gasco J. (2013). Innovation in public services: The case of Spanish local government. Journal of Business Research, 66, 2024-2033. http://dx.doi.org/10.1016/j.jbusres.2013.02.028

Guardiola, J., González-Gomez, F., \& García-Rubio M. A. (2010). Is time really important for research into contracting out public services in cities? Evidence for urban water management in Southern Spain. Cities, 27, 369-376. http://dx.doi.org/10.1016/j.cities.2010.05.004

Herrera, V. (2014). Does Commercialization Undermine the Benefits of Decentralization for Local Services Provision? Evidence from Mexico's Urban Water and Sanitation Sector. World Development, 56, 16-31. http://dx.doi.org/10.1016/j.worlddev.2013.10.008

Kiriyenko, V. E. (2009). "Electronic municipality" as a component of information society of Russia. Management Problems in Social Systems, 1(2), 93-106.

Kozhenko, Y. V., \& Mamychev, A. Y. (2010). Service state: Problems of the theory and practice of realization. Vlast, 3, 44-46. 
Kruks-Wisner, G. (2011). Seeking the Local State: Gender, Caste, and the Pursuit of Public Services in $\begin{array}{llll}\text { Post-Tsunami India. } \quad \text { World } & \text { Development, }\end{array}$ http://dx.doi.org/10.1016/j.worlddev.2010.11.001

Mehmet, Z. S., \& Karkin N. (2013). The use of twitter by mayors in Turkey: Tweets for better public services? Government Information Quarterly, 30, 417-425. http://dx.doi.org/10.1016/j.giq.2013.05.014

Murtazina, L. R. (2010). Changes of social institutes of modern Russian society. In Actual problems of economy, sociology and law in modern conditions: Articles and Theses of Reports of the 5th International scientific and practical conference (Vol. 2, pp. 36-39). Pyatigorsk: Publishing House of the International Academy of Financial Technologies.

Patrick, F. (2000). 'Public service motivation' as an argument for government provision. Journal of Public Economics, 78, 275-299.

Purcărea, V. L., Gheorghea, I. R., \& Petrescu, C. M. (2013). The Assessment of Perceived Service Quality of Public Health Care Services in Romania Using the SERVQUAL Scale. Procedia Economics and Finance, 6, 573-585. http://dx.doi.org/10.1016/S2212-5671(13)00175-5

Rykhtikova, L. Y. (2003). Servants or creation of the "service" model in Russia. Retrieved from http://www.allpravo.ru/library/doc108p0/instrum6231/item6232.html

Rysayev, I. S., \& Habibrakhmanova, E. H. (2010). Participation of social subjects in decision-making as a basis of overcoming of social and administrative alienation in local government. Vlast, 8, 68-71.

Sapko, O. V. (2009). Practical aspects of introduction of quality management system standards ISO 9001: 2008 in public authorities and local government. The Municipal government, 10, 17-23.

Shatayeva, G. V. (2010). Attitude of the population to the reform of local government: Criteria and indicators of human development. Vestnik of MGIMO university, 5, 227-234.

Shuba, K. D. (2010). Local government in modern Russia: Achievements and problem. Vlast, 8, 65-67.

Speer, J. (2012). Participatory Governance Reform: A Good Strategy for Increasing Government Responsiveness and Improving Public Services? World Development, 40(12), 2379-2398. http://dx.doi.org/10.1016/j.worlddev.2012.05.034

Styrin, E. M. (2006). The electronic government: Formation and development strategy. Thesis for Candidate of Sociological Sciences. Moscow, Lomonosov Moscow State University.

Suchkov, A. I., \& Rybakov, Yu. I. (2013). Participation as factor of effective planning of development of rural settlements. In Actual problems of management and economy: Russian and foreign experience: Proceedings of the All-Russian scientific and practical conference (with the international participation) (pp. 110-115). Tomsk.

Winters, M. S., Karim A. G., \& Martawardaya B. (2014). Public Service Provision under Conditions of Insufficient Citizen Demand: Insights from the Urban Sanitation Sector in Indonesia. World Development, 60, 31-42. http://dx.doi.org/10.1016/j.worlddev.2014.03.017

Zinchenko, G. P. (2013). Rural authorities—20 years later. Sociological researches, 7, 104-109.

\section{Copyrights}

Copyright for this article is retained by the authors, with first publication rights granted to the journal.

This is an open-access article distributed under the terms and conditions of the Creative Commons Attribution license (http://creativecommons.org/licenses/by/3.0/). 